\title{
Sources of Rail Transport Efficiency in Supply Chains
}

\author{
${ }^{* 1}$ Natalia P. Karpova, ${ }^{2}$ Sergei V. Noskov, ${ }^{3}$ Irina A. Toymentseva, ${ }^{4}$ Elena V. Shvetsova \\ ${ }^{* 1}$ Doctor of Economics, Professor, Associate Professor, Samara State University of Economics, Samara, Russia. \\ ${ }^{2}$ Doctor of Economics, Professor, Professor, Samara State University of Economics, Samara, Russia. \\ ${ }^{3}$ Doctor of Economics, Professor, Associate Professor, Samara State University of Economics, Samara, Russia. \\ ${ }^{4}$ Candidate of Economic Sciences, Associate Professor, Samara State University of Economics, Samara, Russia. \\ E-mail:"natk08@rambler.ru,noskov50@yandex.ru,tia67@rambler.ru,shvetsova.e@mail.ru
}

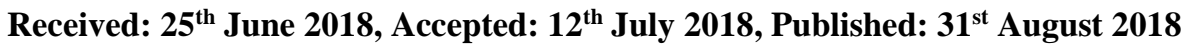

\begin{abstract}
Railway transport is of special strategic importance for Russia. The unconditional leader of both the domestic and the world rail transport market is JSC "Russian Railways" with a charter capital of 2212238.7 million rubles. Given the technical characteristics of the company, it is worth noting that the operational length of railways of JSC "Russian Railways" is 85.5 thousand $\mathrm{km}$; the number of freight cars of all types - 196,300, freight trunk locomotives - 11,8 thousand, passenger locomotives - 3,1 thousand, passenger carriages of long-distance - 21 thousand. JSC "Russian Railways" - being a participant in the supply chain needs to find sources for enhancing efficiency of its activities. In this regard, the objective of this study is to determine the sources of the company's performance in the process of its interaction with suppliers of material and technical resources, on the one hand, and consumers of services, on the other. For this purpose, the research work analyzes the main indicators of commercial activity of JSC "Russian Railway"; reveals trends and prospects for the company's development. To improve the management of suppliers of material and technical resources for the needs of JSC "Russian Railways", the company's strategic goals, activities for their achievement and key indicators of supply efficiency are defined. As part of improving the quality and accessibility of rail transport services the overall level of satisfaction of cargo owners with the quality of railway transport services was carried out.
\end{abstract}

Keywords: Russian Railways, Supply Chain, Logistics, Rail Transport Market, Key Performance Indicators, Freight Flow, Cargo Holders

\section{Introduction}

The railway complex is of strategic importance for Russia, providing freight and passenger transport, stability in matters of national security and international cooperation. The largest player on the railway transport market is JSC "Russian Railways", which is founded by the Russian Federation. In the context of the financial crisis, the search for ways to improve the performance efficiency of a state-owned company in the railway transport market comes to the fore. In turn, under current conditions, each company needs to coordinate its actions with the requirements of partners in the supply chain, satisfying the old requirements and meeting the new ones (Kumar et al., 2017; Banchuen, Sadler \& Shee, 2017) [1-2]. The stability of the entire supply chain is affected by stability indicators of each partner. Relations between counterparties play an important role in increasing the sustainability of the entire supply chain (Kumar \& Rahman, 2015; Waters \& Rinsler, 2014) [3-4]. A wellmanaged supply chain usually establishes strategic and operational objectives, comparing the actions of its participants at each level (Lee \& Nam, 2016; Saak, 2016) [4-5]. Thus, this study covers a set of issues that determine the sources of efficiency of JSC "Russian Railways" in the process of interaction with counterparties in the supply chain. For this purpose, the main business indicators of JSC "Russian Railways" were studied; strategic guidelines were defined in the process of supply management and interaction with suppliers of material and technical resources for the carrier's needs; a methodology for assessing the overall level of satisfaction of cargo owners with the quality of rail transport services was proposed.

\section{Materials and Methods}

To identify the sources of rail transport efficiency in supply chains, the following experimental-theoretical methods were used: analysis, synthesis, analogy, generalization, deduction and induction. To determine strategic benchmarks in supply management of JSC "Russian Railways", the authors used a strategic management tool - Balanced Scorecard, BSC, developed by R.S. Kaplan and D.P. Norton (Kaplan 2004, 2009; Kaplan \& Norton, 1996, 2017) [7-10] and the projection "logistics" was developed and supplemented in the BSC by D.I. Tokarev (2004) [11]. To formulate a methodology for assessing suppliers in JSC "Russian Railways", an expert method was used with the involvement of specialists from the Center for 
Organizing Competitive Procurement of the Company. The assessment of the general level of satisfaction of cargo owners with the quality of railway transport services was carried out by the method of sociological research. JSC "Russian Railways" was the experimental research base for revealing the sources of railway transport efficiency in supply chains.

The study included several stages. At the first stage, the authors determined the research problem. The second stage involved the collection and analysis of scientific literature on the research problem, as well as the choice of the research methodology. The third stage is directly related to the research: the study of main indicators of commercial activity of JSC "Russian Railways"; determination of strategic landmarks in the process of supply management and interaction with suppliers of material and technical resources for the needs of the carrier; identification of parameters of cargo owners' satisfaction with the quality of railway transport services.

\section{Results}

Railway transport occupies a leading position in the transport system of Russia. JSC "Russian Railways" is the system-forming player on the railway transport market in the Russian Federation. According to the results of 2016, the loading on railway networks of the company amounted to 1127.4 million tons, which is $0.5 \%$ higher than last year. The dynamics of revenues and production costs of JSC "Russian Railways" is shown in Figure 1.

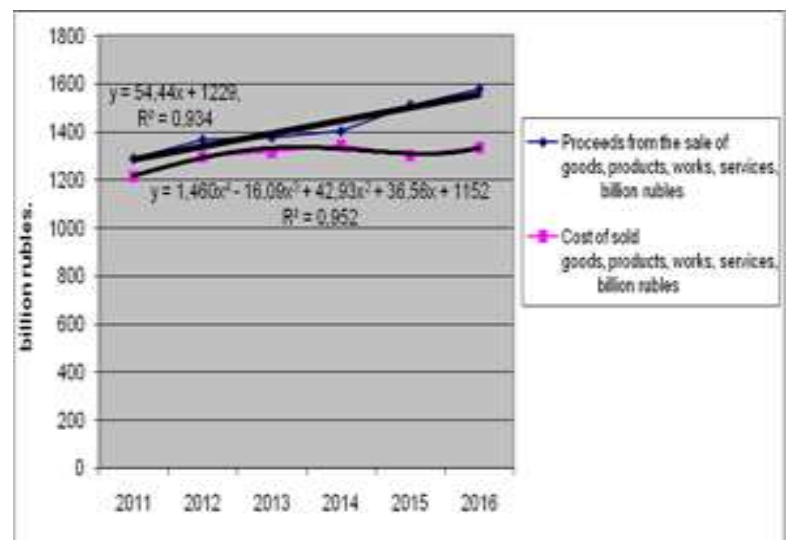

Figure 1. Dynamics of Revenues and Production Costs of JSC "Russian Railways", bln. Rubles. Source: Official site of JSC "Russian Railways" [12].

Analyzing these data, we can conclude that the dynamics of revenue has a positive direction, while revenue growth should be $5.6 \%$ by the end of 2018 compared to 2016. The cost index neither dies nor show favorable dynamics for the analyzed period
(Table 1). According to forecasts, its value will be 1564 billion rubles in 2018 , which is $17.1 \%$ more than the value of 2016 .

\begin{tabular}{|l|l|l|l|l|l|l|}
\hline Indicator & 2011 & 2012 & 2013 & 2014 & 2015 & 2016 \\
\hline $\begin{array}{l}\text { Proceeds } \\
\text { from sale, } \\
\text { bln. rubles }\end{array}$ & 1288,3 & 1366 & 1376,6 & 1401,7 & 1510,8 & 1577,5 \\
\hline $\begin{array}{l}\text { Cost of sales, } \\
\text { bln. rubles }\end{array}$ & 1215,4 & 1298,5 & 1317,7 & 1343,2 & 1302,2 & 1335,0 \\
\hline $\begin{array}{l}\text { Profitability } \\
\text { of } \\
\text { production, \% }\end{array}$ & 6,0 & 5,2 & 4,5 & 4,4 & 6,4 & 8,8 \\
\hline $\begin{array}{l}\text { Profitability } \\
\text { of sales, } \%\end{array}$ & 5,7 & 4,9 & 4,3 & 4,2 & 5,5 & 7,4 \\
\hline $\begin{array}{l}\text { Payments to } \\
\text { suppliers, } \\
\text { bln. rubles }\end{array}$ & 554,9 & 604,1 & 654,9 & 581,5 & 615,4 & 654,2 \\
\hline $\begin{array}{l}\text { Budget } \\
\text { saving for } \\
\text { purchases, \% }\end{array}$ & - & 108,86 & 108,41 & 88,78 & 105,84 & 106,31 \\
\hline
\end{tabular}

Source: Official site of JSC "Russian Railways"

[12].

The data of the table show that the profitability index of products has a non-uniform dynamics: since 2011 there has been a steady trend towards its decrease, which indicates an increase in the cost price of the company's sales. Only in 2016 there was a sharp increase in this indicator. The profitability of the company's sales also tends to fall, which indicates a high cost of rendering services at relatively constant prices for the carrier's services. The profitability of the company's core and current assets has a similar dynamics with the above-described indicators, demonstrating growth only in 2016.

In order to control the cost level in JSC "Russian Railways", it is necessary to develop a sound management strategy for suppliers and supply. The spectrum of the company's needs in the process of providing its own needs is wide enough and is represented by raw materials, traction rolling stock, cars, electric trains, track equipment, spare parts, etc. The main condition for choosing a supplier of resources for the needs of JSC "Russian Railways" is the quality of supply (Linders et al., 2014) [13]. The integral assessment of each counterparty in the company is formed on the basis of such criteria as: a quality level of supplied products (quarterly); a reliability level of supply (quarterly); a supplier loyalty (annually); a supplier perspective (annually). Each of these criteria is calculated by its scores and weights. Quality indicators of products supplied to JSC "Russian Railways" include: a quality of products and services at the time of delivery, during installation and operation; a share of failures in the period of operation; a reliability of supply of material and technical resources. The reliability level of supply in the company can be characterized by such parameters 
as (Sergeeva, 2013) [14]: a compliance with the schedule and volume of deliveries; a timely compensation of losses from defects; a warranty service of supplied material and technical resources. The supplier loyalty can be assessed at the expense of (Bauersoks, Closs \& Cooper, 2012; Bauersoks \& Kloss, 2017) [15-16]: responsiveness to claims and effectiveness of measures taken; elimination of causes that result in defects; availability of information on exit tests and measures taken from the supplier. The supplier perspective is characterized by the availability of a quality management system; the ability of the counterparty to tighten the standards for quality; the supplier's desire for technical development; the level of qualification of the supplier's personnel. In order to improve suppliers' performance, it is recommended to enhance the existing methodology for the assessment of counterparties of products for the needs of JSC "Russian Railways" by including, firstly, the criteria for prices of supplied material and technical resources, the availability of pre-sale and post-warranty services, spare parts, interchangeability of products in the list of quality indicators of delivered products. The list of reliability indicators of supply criteria, characterizing the flexibility of supply, should include the time of the order, the location of the supplier, its financial stability.
In order to determine strategic orientations of JSC "Russian Railways", supply management and suppliers in supply chains, it is recommended to determine strategic objectives, activities and key performance indicators of supply on the basis of the Balanced Scorecard methodology (Table 2) (Kaplan 2004, 2009; Kaplan \& Norton 1996, 2017; Tokarev, 2004) [7-10; 11].

It is important to note that, in the current situation, key suppliers of material resources for the needs of JSC "Russian Railways" should be oriented towards compliance with the listed strategic supply goals, since with the growth of globalization and competition it is necessary to understand that none can do business alone: supply chain management should become a strategic reference for firms, which will improve the entire supply chain efficiency (Biggemann et al., 2013) [17].

Activities aimed at establishing long-term partnerships and motivating suppliers of JSC "Russian Railways" to achieve the highest product quality and service quality should have the following long-term goals: striving for defect-free supply of products; "zero deviations from the delivery time"; constant improvement of products, processes; price restraint due to cost production management of products or services (increase efficiency); constant improvement of the quality of services.

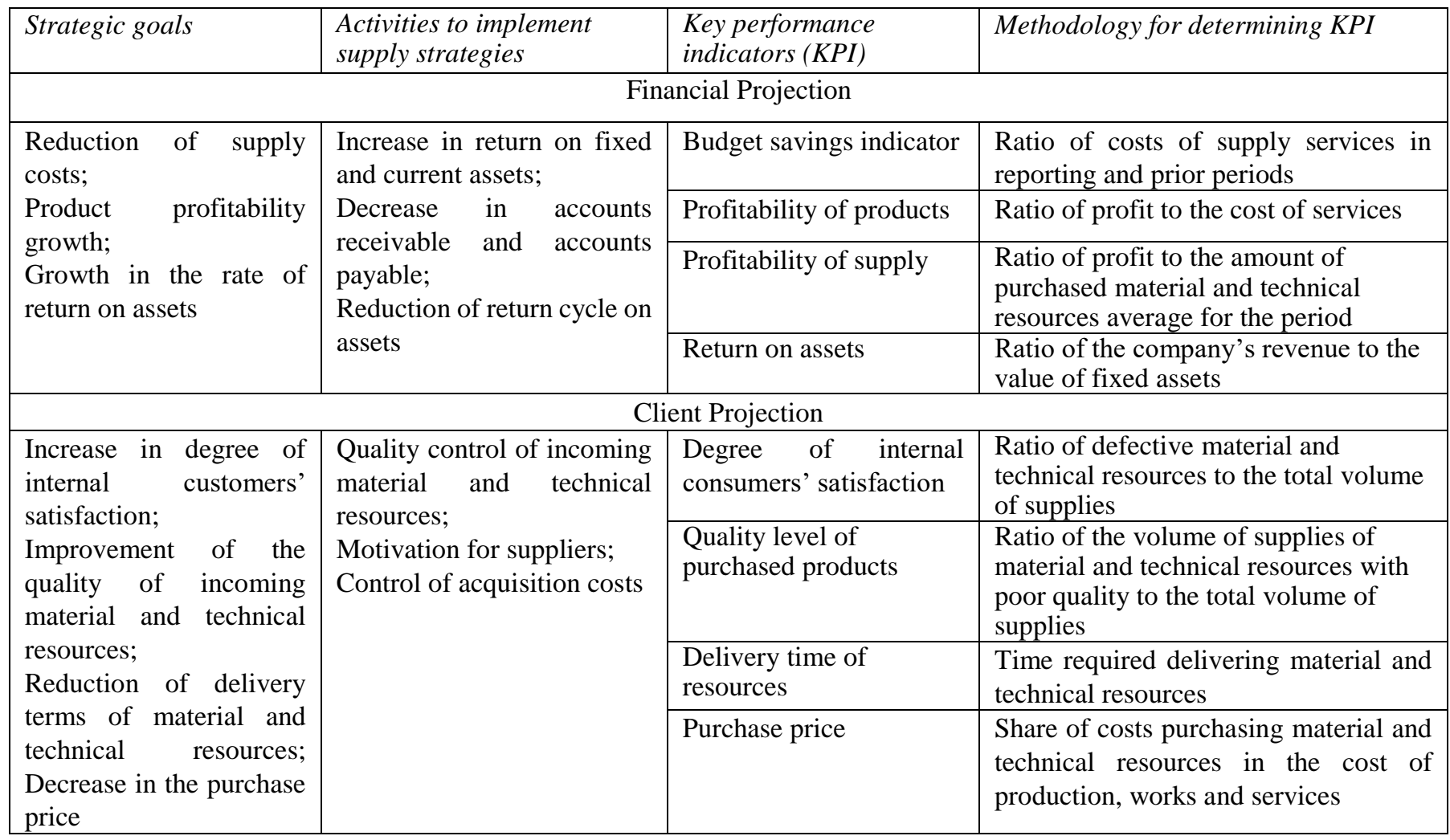




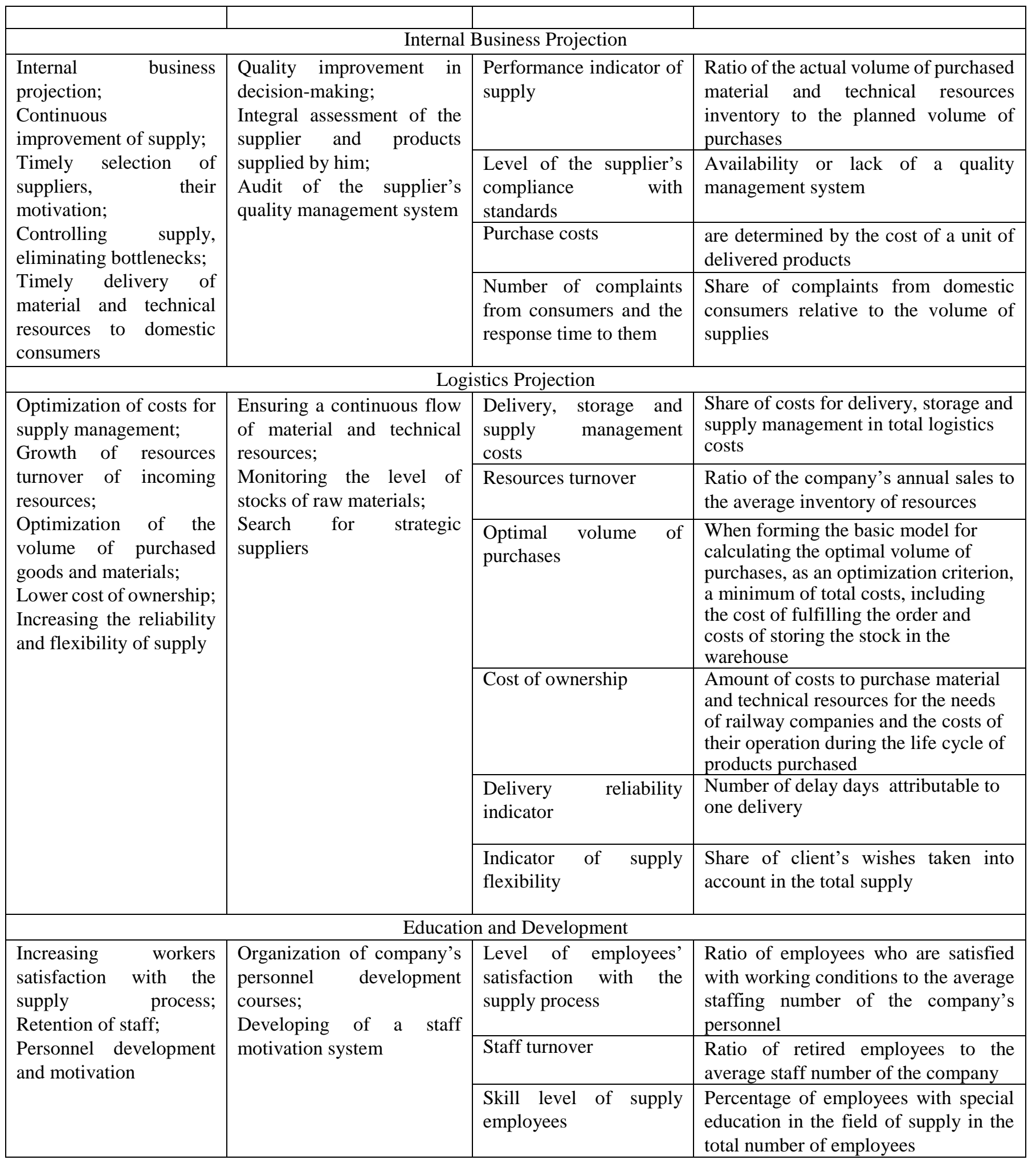

Table 2. Strategic Goals for the Supply Process and Measures to achieve them in JSC "Russian Railways"

In order to strengthen cooperation in the company, various methods of motivating suppliers for the needs of JSC "Russian Railways" (Karpova, 2011) [18] should be applied: advantages of holding a tender; long-term contracts; advantageous purchase prices; advance investment payment; investment; provision of equipment; preferential participation in conferences of JSC "Russian Railways", opportunities to make a 
presentation and invite subcontractors; corporate training; consulting support; information support; working groups at the level of JSC "Russian Railways". The different methods of motivation should vary according to the supplier category: "quality leader", "excellent supplier", "good supplier”, “acceptable supplier”, "unacceptable supplier'. The higher the category, the more motivational activities are used when interacting with it in supply chains. It is believed that the motivation of the supplier positively stimulates it, including the development of innovations that meet customers' needs (Vieira \& Bonifácio-da-Silva, 2016) [19]. In this case, the supply chain should be seen as a conduit for knowledge dissemination (Todo, Matous \& Innoue, 2016) [20].

\begin{tabular}{|l|l|l|l|l|l|l|l|l|l|l|}
\hline \multirow{2}{*}{ Indicators } & \multicolumn{2}{|l|}{ Year } & \multicolumn{2}{l|}{ Fluctuation by years } & \multicolumn{3}{l|}{ Growth rate, \% } \\
\cline { 2 - 10 } & 2014 & 2015 & 2016 & $\begin{array}{l}2015 \\
\text { from } \\
2014\end{array}$ & $\begin{array}{l}2016 \\
\text { from } \\
2015\end{array}$ & $\begin{array}{l}2016 \\
\text { from } \\
2014\end{array}$ & $\begin{array}{l}2015 \\
\text { from } \\
2014\end{array}$ & $\begin{array}{l}2016 \\
\text { from } \\
2015\end{array}$ & $\begin{array}{l}2016 \\
\text { from } \\
2014\end{array}$ \\
\hline $\begin{array}{l}\text { Freight turnover, } \\
\text { bln tkm. }\end{array}$ & 2954,5 & 2954,9 & 2997,8 & 0,4 & 42,9 & 43,3 & 100,01 & 101,5 & 101,4 \\
\hline $\begin{array}{l}\text { Passenger turnover, } \\
\text { bln. pass-km. }\end{array}$ & 128,8 & 120,4 & 124,5 & $-8,4$ & 4,1 & $-4,3$ & 93,5 & 103,4 & 96,7 \\
\hline
\end{tabular}

\section{Source: Official site of JSC "Russian Railways" [12].}

In general, JSC “Russian Railways" provides transport services to manufacturing companies in various fields of activity: coal, metallurgy, oil and gas industry, automotive industry, forestry, etc. Consumers of railway transport services face a regular increase in the tariff load, a decrease in the quality of infrastructure facilities and a general decline in the quality of the services provided. Low speed of delivery of goods, bureaucratic barriers, opaque conditions for access to infrastructure, rising tariffs lead to the outflow of goods from railway to other modes of transport (in particular, automobile). In order to compete on an equal footing with other modes of transport, the railway industry needs a deeper and more consistent reform. Proceeding from this, being as much as possible interested in increasing efficiency of rail transport, consumers should become initiators, ideologists and reformers ("The Council of Consumers of RZD services accelerates the reform of the industry") [21] .

In this regard, it is necessary to conduct a study on consumers' assessment of the quality of services, pricing policy, additional services and special offers on the freight transport market. The respondents collected opinions in the fourth quarter of 2017 by questionnaires and interviewing, the survey involved senior and middle managers of companies that are users of services in the freight transport market. In the framework of the questionnaire, respondents were
Also, within the scope of the research objective, it is necessary to trace interaction between JSC "Russian Railways" and another element of the supply chain the consumer. Thus, the dynamics of freight and passenger turnover of the company is presented in Table 3. The analysis of the data in Table 3 shows that the volume of freight turnover in 2015 increased and amounted to 2954.9 billion tkm. In 2016 this indicator increased by 42.9 billion tkm or $101.5 \%$ and was equal to 2997.8 billion tkm. The volume of passenger turnover in 2015 decreased by 8.4 billion pass-km and amounted to 120.4 billion pass-km or $93.5 \%$, and in 2016 it increased by 4.1 billion passenger-km and amounted to 124.5 billion pass- $\mathrm{km}$ or $103.4 \%$. asked to assess the current situation according to certain criteria on a 100-point scale with the classification: 0-25 points - "unsatisfactory", 25-50 "satisfactory", 50-75 - "good", 75-100 "excellent" (participants of the study were informed that the score they put corresponded to one or another estimate). Based on the collected data, the index of the general level of satisfaction with the quality of services was computed, summarizing all the estimates obtained.

The index of the general level of satisfaction with the quality of railway transport services includes the following criteria: the cost of services of JSC "Russian Railways" $\left(\overline{S_{u}}\right)$; the cost of services of companiesoperators $\left(\overline{S_{k}}\right)$; the prompt approval of applications ( $\overline{O_{z}}$ ); the availability of cars of the required type in the required quantity $\left(\overline{N_{v}}\right)$; technical conditions of cars ( $\left.\overline{T_{v}}\right)$; the delivery of cars for loading / unloading according to the schedule $\left(\overline{V_{z}}\right)$; the compliance with the delivery time $\left(\overline{T_{p}}\right)$; the level of information technology and the speed of information transfer $\left(\bar{I}_{t}\right.$ ); the safety of cargo $\left(\overline{C_{g}}\right)$; the level of the transport 
infrastructure development $\left(\bar{T}_{l}\right)$; the level of satisfaction of demand for transport $\left(\overline{D_{p}}\right)$.

The index of the general level of satisfaction with the quality of railway transport services can be determined by the formula 2 :

$\mathrm{n}$ - number of criteria analyzed

The results of the survey of services in the market of freight transport by mainline railway transport are shown in Figure 3.

The index of the general level of satisfaction with the quality of railway transport services was 61 points. The lowest value was recorded in the criterion: "cost of services of companies-operators" - 40 points. The second most unpopular place was the indicator: "cost of services of JSC "Russian Railways" - 49 points. The last indicator in the group of "leaders" was "availability of cars of the required type in the required quantity" - 53 points. Traditionally, almost until 2018 the exact amount of the indexation of tariffs of JSC "Russian Railways" was hidden by a veil of secrecy. Carriers are outraged by total uncertainty, which repeats from year to year. Also, the majority of cargo owners develop a stable impression that the railway transport market works only for large producers, but not for small and medium-sized companies, although there are a lot of them. But if the indexation of tariffs of JSC "Russian Railways" is at least the same for all companies and its size remains unchanged for the whole year, even more claims arise to car components. Its volatility can often face the loss of competitiveness. It is worth noting that the final value by the criterion of the cost of services of companies-operators could have been even lower, if there had not been a trend towards lower rates at the end of the year. Although,
$I_{k}=\frac{\overline{S_{u}}+\overline{S_{k}}+\overline{O_{z}}+\overline{N_{v}}+\overline{T_{v}}+\overline{V_{z}}+\overline{T_{p}}+\overline{I_{t}}+\overline{C_{g}}+\overline{T_{l}}+\overline{D_{p}}}{n}$

as the respondents noted, companies-operators still continued to raise prices until November 2017. As one of cargo owners noted, companies-operators reacted to growing market prices instantly, but as for the market decline, even seasonal, their reaction was usually slow.

Often it is easier for cargo owners to work with small owners of cars, as they tend to find a way to adjust to customers, including in the price issue. There is, however, one drawback: with small players it is more difficult to collect cars into the pool, but all reconciliations take much less time, while with a large company-operator, negotiations can take several days. It is worth noting that this scheme does not suit all cargo owners, but only small ones, with small volumes of shipment. But, on the other hand, large cargo owners do not feel themselves to be "deprived of attention" in view of expanding the practice of concluding long-term contracts.

As a negative point, it can be noted that there is a shortage of cars in the railway transport market from time to time. Even if the cargo owner works under long-term contracts and they are successfully carried out, in the periods when there is a need to ship over the plan, there are no enough cars. It intensifies the carload issue and the lack of rhythm and graphics in the car park supply for loading.

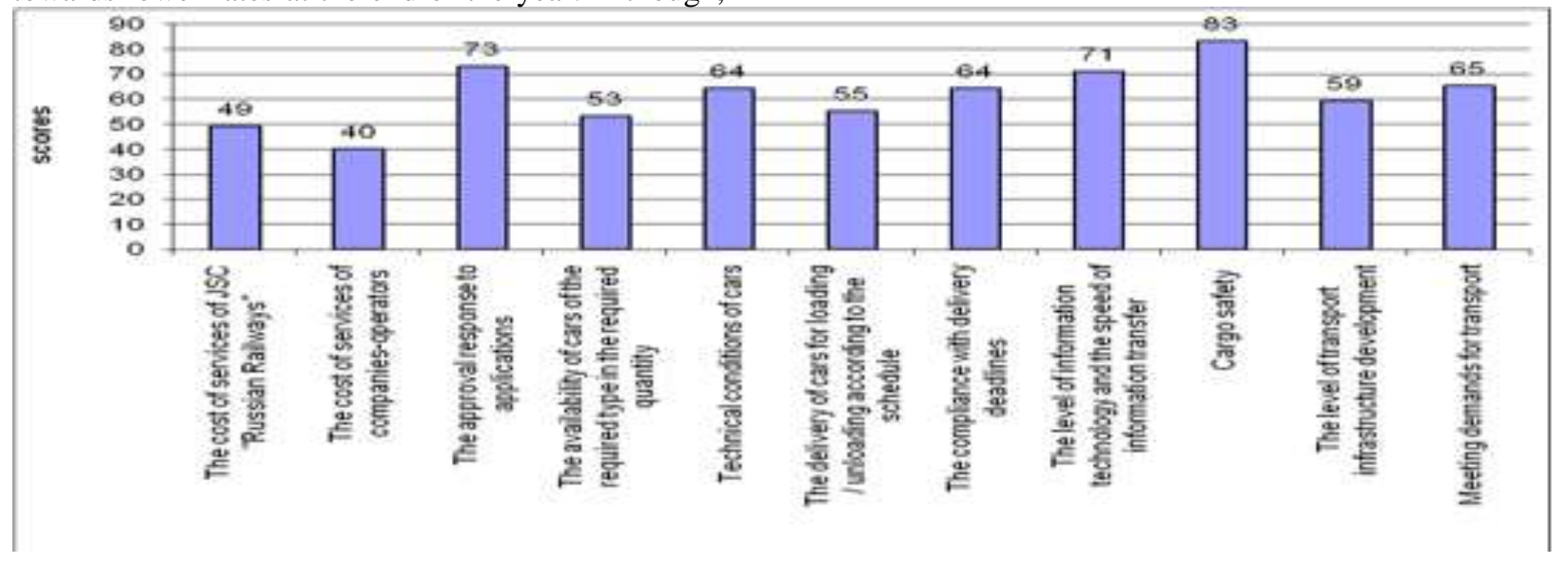

Figure 3. Criteria for the Overall Level of Satisfaction with the Quality of Rail Transport Services

At the same time, many cargo owners agree that the top managers of JSC "Russian Railways" really strive to improve interaction with customers, create conditions for a more efficient transport process, 
introduce new technologies, but on the ground, this work is poorly conducted. It seems that such solutions can be implemented within the framework of the digital railway concept. In general, we believe that the basis for the development of the long-term cooperation of carriers and their consumers in the railway market

\section{Discussion}

The main purpose of the article was to determine sources of efficiency of rail transport companies in the process of their interaction with suppliers of material and technical resources, passengers and cargo owners. According to scientists, isolated operations of companies in modern conditions are impossible.

Companies have to seek compromises constantly and make concessions, negotiating with counterparties in the supply chain. Railway transport companies are not exception. It should be noted that JSC "Russian Railways", a company with state participation, is a monopolist in the railway transport market. Therefore, we believe it is reasonable to extrapolate the conclusions obtained in the course of research into the activities of this company on the whole railway market.

According to the Strategy for the development of rail transport in the Russian Federation until 2030 [22], among the strategic reference points of carriers can be identified: the formation of conditions for sustainable socio-economic development of the whole country, increasing the mobility of the population and optimizing the delivery of material assets to the end user, reducing total transport costs of the Russian economy. This is further confirmed by the fact that the integrated approach should be applied to the management of rail transport, which helps to build long-term mutually beneficial relations with counterparties in supply chains. This leads to the need to develop key suppliers based on joint development of BSC. To this end, strategic goals of supplying JSC "Russian Railways", measures for their achievement have been proposed in the work; key indicators of supply chain efficiency of rail transport companies were outlined. Developing the theory of strategic interaction with key suppliers of material and technical resources, the methodology on forming assessment of suppliers of JSC "Russian Railways" was proposed, and methods for motivating counterparties were recommended, which will help achieve high quality of supplies.

Considering the aspects of interaction between carriers and cargo owners, a mechanism for determining the overall level of satisfaction with the quality of railway transport services was proposed and tested. The results of the research confirmed the fact that the main problems in the development of is the strategy for mutual harmonization of relations, which should be understood as the process of mutual coordination and harmonization of economic interests in supply chains.

the relationship between carriers and cargo owners in the supply chain are: a constant increase in tariffs for railway transport services, a poor quality of the logistics infrastructure and services provided by carriers. Thus, only a competent integrated approach will eliminate the identified problems of the rail transport operation in supply chains.

\section{Conclusion}

The railway industry in our country satisfies the needs of the state, population and companies in rail freight and passenger transport. The conducted research made it possible to determine a set of measures to improve the transport system efficiency in supply chains. For this purpose, the main indicators of Russian Railways were analyzed: the company's profitability, the dynamics of profit and loss indicators, the cost of services, and the growth which revealed the need to search for sources of its reduction. Also, a mechanism for interaction with suppliers of material and technical resources for the needs of JSC "Russian Railways" was proposed, strategic guidelines, actions for their achievement and key indicators of the carrier's supply efficiency were identified.

In order to identify problems and determine sources for the efficiency of carriers' activities, the study was conducted on the overall level of cargo owners' satisfaction with the quality of railway transport services by such parameters as: the cost of services of JSC "Russian Railways"; the cost of services of companies-operators; the prompt approval of applications with cargo owners; the availability of cars of the required type in the required quantity; technical conditions of cars; the possibility of submitting cars for loading / unloading according to the schedule; the compliance with the delivery time; the level of information technology and the speed of information transfer; the safety of cargo; the level of transport infrastructure development; the level of satisfaction of demand for transport.

\section{Acknowledgements}

The study was carried out with the financial support of the Russian Foundation for Basic Research, project No. 17-02-00155 "Strategic solutions in supply logistics for railway transport companies".

\section{References}

[1] Kumar, G., Banerjee, R.N., Meena, P.L., Ganguly, K.K. (2017). Joint planning and problem 
solving roles in supply chain collaboration. IIMB Management Review, 29(1), pp. 45-57. Retrieved from: http://ac.els-cdn.com/S0970389617300782/1s2.0-S0970389617300782-main.pdf?_tid=4817dc2a5c04-11e7-a54000000aab0f27\&acdnat $=1498656091 \_54 c 55143 \mathrm{fd} 5 \mathrm{~b} 8$ f3302f48367a84b2ae4.

[2] Banchuen, P., Sadler, I., \& Shee, H. (2017). Supply chain collaboration aligns order-winning strategy with business outcomes. IIMB Management Review, 29(2), pp. 109-121.Retrieved from: http://ac.els-cdn.com/S0970389617302240/1-s2.0-

S0970389617302240-main.pdf?_tid=0e0f50c0-5c0511e7-baa4-

00000aacb35f\&acdnat=1498656423_c5157e1cdba91 93d6b66fce5ea4856ad.

[3] Kumar, D., \& Rahman, Z. (2015). Sustainability adoption through buyer supplier relationship across supply chain: A literature review and conceptual framework. International Strategic Management Review, 3(1-2), pp. 110-127. Retrieved from: http://ac.els-cdn.com/S2306774815000046/1s2.0-S2306774815000046-main.pdf?_tid=12bec67c$5 \mathrm{c} 06-11 \mathrm{e} 7-\mathrm{b} 8 \mathrm{c} 2-$

00000aab0f02\&acdnat $=1498656861 \_491 \mathrm{f} 800 \mathrm{~b} 4 \mathrm{a} 211$ 08c7b0d00020c0e16f3.

[4] Waters, D., \& Rinsler, S. (2014). Global Logistics: New Directions in Supply Chain Management. 7th Edition.GB \& USA by Kogan Page. [5] Lee, T., \& Nam, H. (2016). An Empirical Study on the Impact of Individual and Organizational Supply Chain Orientation on Supply Chain Management. The Asian Journal of Shipping and Logistics, 32(4), pp.249-255. Retrieved

from:http://www.sciencedirect.com/science/article/pii /S2092521216300852.

[6] Saak, A.E. (2016). Traceability and reputation in supply chains. International Journal of Production Economics, Vol. 177, pp. 149-162.

Retrieved from: http://www.sciencedirect.com/scienc e/article/pii/S0925527316300342.

[7] Kaplan, R.S. (2004). Strategy Maps: Converting Intangible Assets into Tangible Outcomes. Concentrated Knowledge ${ }^{\mathrm{TM}}$ for the Busy Executive, 26(4) (2 parts), Part 1, pp. 1-8. Retrieved from: http://strategus.it/files/Strategy-Maps.pdf.

[8] Kaplan, R.S. (2009). Conceptual Foundations of the Balanced Scorecard. Handbooks of Management Accounting Research, Vol. 3, pp. 12531 269. Retrieved from: http://www.sciencedirect.com/s cience/article/pii/S1751324307030039.

[9] Kaplan, R.S., \& Norton, D.P. (1996). The Balanced Scorecard: Translating Strategy into Action New York: Harvard Business Press.
[10] Kaplan, R.S., \& Norton D.P. (2017). The Balanced Scorecard. From strategy to action. Moscow: Olimp-Biznes.

[11] Tokarev, D.I. (2004). Strategic logistics in supply chain management (using the example of automobile enterprises). Thesis for the degree of Candidate of Economic Sciences. Samara: Samara State Academy of Economics, $171 \mathrm{p}$.

[12] Official site of JSC "Russian Railways". Retrieved from: http://ir.rzd.ru/isvp/public/ir?STRUCTURE_ID=32\& nc $=1 \# 2$.

[13] Linders, M.R., Dzhonson, F., Flinn, A.Ye., Firon, G. (2014). Purchase and supply management. Moscow: Yuniti-Dana.

[14] Sergeeva, V.I. (2013). Corporate Logistics. 300 Answers to Questions of Professionals. Moscow: INFRA-M.

[15] Bauersoks, D., Closs, D., \& Cooper, M. (2012). Supply Chain Logistics Management. 4th Edition. New York: McGraw-Hill Education.

[16] Bauersoks, D., \& Kloss, D. (2017). Logistics. Integrated Supply Chain. Moscow: Olimp-Biznes.

[17] Biggemann, S., Kowalkowski, C., Maley, J., Brege, S. (2013). Development and implementation of customer solutions: A study of process dynamics and market shaping. Industrial Marketing Management, 42(7), 1083-1092. Retrieved from: https://www.sciencedirect.com/science/article/pii/S00 19850113001569.

[18] Karpova, N.P. (2011). Definition of supply strategies for railway companies. Vestnik of Samara State University of Economics, 4(78), pp. 36-42.

[19] Vieira, V.A., Bonifácio-da-Silva, W. (2016). An analysis of the relationship between embedded ties and supplier innovation in the cooperative sector. Revista de Administração, 51(4), pp. 386-

396. Retrieved from:https://www.sciencedirect.com/s cience/article/pii/S0080210716301753.

[20] Todo, Y., Matous, P., \& Inoue, H. (2016). The strength of long ties and the weakness of strong ties: Knowledge diffusion through supply chain networks. Research Policy, 45 (9), pp.1890-

1906. Retrieved from:https://www.sciencedirect.com/ science/article/pii/S0048733316301056.

[21] The Council of Consumers of RZD services accelerates the reform of the industry [Electronic resource].Retrieved from: https://rg.ru/2017/06/27/so vet-potrebitelej-uslug-rzhd-uskoriaet-reformuotrasli.html.

[22] The strategy for the development of rail transport in the Russian Federation until 2030: the order of the Government of the Russian Federation of June 17, 2008. No. 877-r [Electronic resource]. Retrieved from: http://doc.rzd.ru/doc/public/ru?STR UCTURE_ID=704\&layer_id=5104\&id=3997. 